OPEN ACCESS

Edited by:

David Bruyette,

Anivive Lifesciences, United States

Reviewed by:

Dilip Kumar Garikipati, Cleveland Clinic, United States John Damian Chretin,

VCA West Los Angeles Animal Hospital, United States

*Correspondence:

Olga V. Matveeva

olga.matveeva@gmail.com

Specialty section:

This article was submitted to Comparative and Clinical Medicine,

a section of the journal

Frontiers in Veterinary Science

Received: 26 September 2017

Accepted: 15 May 2018

Published: 04 June 2018

Citation:

Ilyinskaya GV, Mukhina EV, Soboleva AV, Matveeva OV and Chumakov PM (2018) Oncolytic Sendai Virus Therapy of Canine Mast

Cell Tumors (A Pilot Study). Front. Vet. Sci. 5:116. doi: 10.3389/fvets.2018.00116

\section{Oncolytic Sendai Virus Therapy of Canine Mast Cell Tumors (A Pilot Study)}

\author{
Galina V. Ilyinskaya ${ }^{1,2}$, Elena V. Mukhina ${ }^{3}$, Alesya V. Soboleva ${ }^{1,4}$, Olga V. Matveeva ${ }^{5 *}$ and \\ Peter M. Chumakov ${ }^{1,4}$
}

${ }^{1}$ Engelhardt Institute of Molecular Biology, Moscow, Russia, ${ }^{2}$ Blokhin Cancer Research Center, Moscow, Russia, ${ }^{3}$ Veterinary Clinic of Herzen Oncology Research Institute, Moscow, Russia, ${ }^{4}$ Chumakov Federal Scientific Center for Research and Development of Immune-and-Biological Products, Moscow, Russia, ${ }^{5}$ Biopolymer Design LLC, Acton, MA, United States

Background: Canine mastocytomas (mast cell tumors) represent a common malignancy among many dog breeds. A typical treatment strategy for canine mastocytomas includes surgery, chemo- and radio-therapy, although in many cases the therapy fails and the disease progression resumes. New treatment approaches are needed.

Aims: The goal of this pilot study was to examine safety and efficacy of oncolytic Sendai virus therapy administered to canine patients with cutaneous or subcutaneous mastocytomas.

Materials and Methods: Six canine patients, with variable grades and stages of the disease, received virus therapy, either as a monotherapy, or in combination with surgery. The therapy included two or more virus applications administered weekly or biweekly. Each application of Sendai virus $\left(10^{7}-10^{8.6}\right.$ EID50) consisted of multiple individual 0.01-0.1 ml injections delivered intratumorally, intradermally around a tumor, and under a tumor bed.

Results: The treatment was well tolerated, with minor transitory side effects. Of the six dogs, two did not receive surgery or any other treatment besides the virus injections. The other four animals underwent radical or debulking surgeries, and in three of them the subsequent administration of Sendai virus completely cleared locally recurrent or/and remaining tumor masses. Five dogs demonstrated a complete response to the treatment, the animals remained disease free during the time of observation (2-3 years). One dog responded only partially to the virotherapy; its after-surgical recurrent tumor and some, but not all, metastases were cleared. This dog had the most advanced stage of the disease with multiple enlarged lymph nodes and cutaneous metastases.

Conclusion: The results of the pilot study suggest that Sendai virus injections could be safe and efficient for the treatment of dogs affected by mastocytomas. They also suggest the need of further studies for finding optimal schemes and schedules for this kind of therapy.

Keywords: canine mastocytoma, mast cell tumor, MCT, oncolytic virus, Sendai virus, virotherapy 


\section{INTRODUCTION}

Mast cell tumors (MCTs) are common canine malignancies representing up to $20 \%$ of canine skin cancers. Usually they are diagnosed by fine needle aspiration (1-3). A treatment strategy for these tumors represents a challenge because MCT response to a treatment is highly variable and the advanced disease is frequently lethal $(2,3)$. The age distribution of MCT onset peaks from 6 to 8 years. Frequency of occurrence varies between breeds. Beagles, bulldogs, Boxers, Boston terriers, Rhodesian ridgebacks, pugs, Weimaraners, Labradors, and golden retrievers develop MCTs most frequently (4-6). Some breeds, such as Pugs, tend to develop less aggressive and more differentiated tumors (7). In contrast, Labrador retrievers and golden retrievers develop more aggressive mastocytomas (3). Appearance of these tumors is highly variable; they might be represented by raised or very deep lesions. Some dogs develop solitary and some multiple lesions. The multiple lesions might be represented by related or unrelated MCTs (1-3).

Normal mast cells, which represent a subtype of white blood cells, have multiple roles in immune system functioning. They are involved in defense against pathogens and in wound healing. Mast cells derive from pluripotent CD34+ hematopoietic stem cells that reside in bone marrow (8). Mast cells are located in connective tissue and, when activated, rapidly release the contents of their granules-histamine, proteases, cytokines and heparin-into the interstitium contributing to the inflammation response (9). Dysfunctional release of the contents of MCT's granules produces significant secondary damage such as gastric ulcers, internal bleeding, and a range of allergic reactions (10).

The outcome of MCT disease depends on many factors. Survival time is linked to MCT's grade, stage, the location of the primary tumor, status of surgical margins, and mitotic index (number of mitotic figures per 10 high-power fields) (11-15). The following criteria are employed for MCT's grade assignment; type of cell arrangement, shape of cells, presence of ample cytoplasm and cytoplasmic boundaries, shape of nuclei, type, and size of intra-cytoplasmic granules, presence of giant and multinucleated cells, mitotic index, and presence of edema, necrosis and hemorrhage $(16,17)$. The most common grading system for cutaneous MCT developed by Patnaik et al. (16) defines grade 1 as a tumor formed by well-differentiated, grade 2 -by an intermediate, and grade 3 -by poorly differentiated mast cells. The disease grade correlates with survival rate. After a surgery $93 \%$ of animals with grade 1 MCT survived at least 4 years, however only $44 \%$ of animals with MCT grade 2 and $6 \%$ with MCT grade 3 survived that long (16).

Kiupel system of cutaneous MCT grading is more recent, more precise and achieves better agreement among veterinary pathologists. Moreover, it more accurately predicts MCT's biological behavior. The system defines only two histological categories, high-grade and low-grade. High-grade tumors were related to shorter survival time, on average $<4$ months. In contrast, for low-grade MCT average survival time was more than 2 years. Such features as mitotic index of 7 or more, presence of 3 or more multinucleated cells, presence of 3 or more bizarre nuclei, or detection of karyomegaly in 10 high power fields define high-grade tumors (17). Kiupel MCT grading system is more specific and clear cut, yet many veterinary pathologists prefer using Patnaik grading system. Patnaik system was used in the present study.

Other factors such as intratumoral blood vessel density (18), neutrophil to lymphocyte ratio (19), and leukocyte profile and count (20) were also shown to play a role in survival prognosis. Analysis of genomic alterations has revealed some useful prognostic markers, such as deletions within PTEN and FAS and amplifications of MAPK3, WNT5B, FGF, FOXM1, and RAD51 genes, which were associated with shorter survival times (21). Also, certain haplotypes harboring the hyaluronidase genes were identified as disease associated risk factors (22). Finally, a connection was found between c-KIT gene mutations, elevated c-KIT mRNA expression and a higher grade of tumor $(15,23-$ 27). Consequently, c-KIT mutations in tumor tissues are related to shorter survival times $(28,29)$. These mutations are present in $50 \%$ of high grade and in $9-15 \%$ of overall MCT cases $(28-30)$.

Surgery is an effective treatment for well- or intermediatedifferentiated tumors, but only if the disease did not spread from the original location. In dogs subjected to surgery alone, margins status and tumor grade predict the disease outcome. As expected, infiltrated margins and high tumor grade (according to Kiupel system) were related to higher reoccurrence rate (31). Tumorfree margins of $3 \mathrm{~mm}$ were shown to be sufficient to prevent reoccurrence of low-grade tumors (13). However, high-grade tumors reoccurred frequently ( $50 \%$ or more), despite the width of their tumor-free margins $(16,32)$.

There is no standard protocol for MCT treatment and the only FDA-approved drug is Toceranib (Palladia) (33). However, different treatment options that include radiation and variable chemotherapeutic protocols have been established in many veterinary facilities. Relevant publications with treatment side effects and efficacy results are listed in Table 1. Many treatment protocols provide significant life extension for canine patients. However, the treatment failure rate for advanced MCTs is high and none of the large-scale clinical trials have achieved longlasting complete response rates exceeding 15\%. Radio- and cytostatic chemotherapy are less effective against tumor cells that divide slowly, and the absence of c-KIT mutations makes the tumors less likely to respond to protein kinase inhibitors $(33,45)$. So, tumors with comparatively low mitotic index or without cKIT mutations, which represent up to $80 \%$ of MCT malignancies (12), are much less treatable by chemotherapy or radiation.

Oncolytic virotherapy is an emerging therapeutic option for cancer treatment. However, there are very few reports that describe its application in veterinary medicine. An adenovirusbased construct was tested for treatment of aggressive canine melanomas (47). One dog in this study was diagnosed with an advanced stage III oral melanoma. A combination of viral treatment and cytoreductive surgery caused complete tumor clearance and long term disease free survival of this dog. Another dog was diagnosed with conjunctival melanoma that progressed very rapidly. Multiple viral injections without surgery caused disease stabilization and long progression free survival of this dog (47). A different study with the same adenovirus construct introduced by a few intratumoral injections ended with 
complete responses in 5 out of 19 dogs affected by malignant melanomas (48). Three relatively recent reviews summarize results of oncolytic viruses-based therapeutic approaches for canine malignancies (49-51).

Oncolytic potentials of Sendai virus have been studied mainly in Japan. Sendai virus belongs to Paramyxoviridae family and its pathogenicity is host-restricted to rodents (52). It can produce transmittable respiratory tract infections in mouse colonies worldwide (52) and is completely safe for humans $(53,54)$.

A number of studies have demonstrated that an attenuated (through genetic engineering) Sendai virus loses its pathogenicity for rodents. However, it can spread in tumors and kill malignant cells, while sparing the surrounding normal cells. The virus was shown to suppress or completely eradicate a number of tested experimental tumors, including xenografted human tumors, including fibrosarcomas, neuroblastomas, pancreatic, colon, and prostate carcinomas (55-58). A number of human tumors in rat xenograft models also responded to Sendai virus therapy including melanomas, neuroblastomas, squamous cell, hepatocellular, and prostate carcinomas (59). Even after inactivation with ultraviolet light, Sendai virus particles were able to suppress or eradicate colon (60), bladder (61), and kidney (62) cancers in syngeneic murine models. Similar results were demonstrated for mouse xenografts of human prostate cancer (63).

The present report describes six canine MCT cases treated with Sendai virus strain attenuated through multiple passages in embryonated chicken eggs. In the study we used two different dosages of the virus in order to get information if doses with a lower titer would be able to clear the tumors, and if doses with a higher titer would cause unwanted side effects.

\section{MATERIALS AND METHODS}

Protocols and procedures described in this study were reviewed and approved by the animal ethics committee of the Veterinary Clinic of Herzen Oncology Research Institute.

\section{Tumor Grading and Staging}

Tumors were graded according to Patnaik et al. (16) by a single board-certified veterinary pathologist. The following criteria were used for grade assignment: cell arrangement; shape of cells and their nuclei; presence of cytoplasmic boundaries; type, quantity, and size of intra-cytoplasmic granules; mitotic index; and presence of multinucleated cells, edema, necrosis, and hemorrhage. Histological examination was not performed for cases 1 and 6 because the animals didn't undergo surgical treatment. So, the determination of tumor grade for these cases was based on cytology only and, consequently it was less precise in comparison with other cases. Tumors staging for case 1 and case 6 was not performed. Primary diagnosis was established by fine-needle aspiration technique, and if a surgery was performed, the diagnosis was a subject of confirmation by histological examination of the excised tumor. Mitotic index for histological examination was evaluated per 10 high-power (400 X) fields (HPF), field size $2.7 \mathrm{~mm}^{2}$. Secondary growth and lymph nodes were examined using fine-needle aspiration. Tumor staging was done by histological examination of excised tumor masses, by palpation and fine-needle aspiration of lymph nodes and visible metastases. The staging was not very precise because radiography, ultrasound, bone marrow, and organ biopsies were not performed.

\section{Prednisone Treatment}

To avoid any immunosuppressive effects prednisone was not routinely administered during Sendai virus therapy. However, one dog (case 3), which had the most advanced disease, was treated with regular daily oral prednisone $(1 \mathrm{mg} / \mathrm{kg})$ as palliative care during 28 days before euthanasia. Another dog (case 5) was treated once with injectable prednisone $(2 \mathrm{mg} / \mathrm{kg})$ after an mastocytoma degranulation event that was not related to the viral treatment.

\section{Viral Preparation}

Sendai virus was prepared as described (64) with some modifications. In brief, diluted virus seed (100 ul) was inoculated into allantoic cavity of 10-day embryonated eggs. Virus containing allantoic fluid was harvested after 3 days of incubation at $37^{\circ} \mathrm{C}$. The virus titer was determined by infection of embryonated eggs with serial dilutions and expressed as $50 \%$ Egg Infective Dose/ml (EID50/ml). Sendai virus material used in animal experiments was manufactured by two different procedures that were performed in two different facilities. The first preparation was done in our research facility and included virus purification as well as concentration through ultra-filtration dialysis of collected allantoic fluid. The second virus preparation was purchased from Charles River Laboratory (North Franklin, CT 06254). It included Sendai virus-containing allantoic fluid without any purification that was directly lyophilized, and used upon rehydration.

\section{Virus Purification by Ultra-Filtration Dialysis}

Virus-containing allantoic fluid was clarified using low-speed centrifugation $(1,500 \mathrm{~g}$ for $10 \mathrm{~min})$ and subjected to ultrafiltration with a Pellicon 2 cassette (Millipore, mini Ultrafiltration Module Biomax-C $0.1 \mathrm{~m}^{2}$ [P2B300C01]). The initial sample volume was reduced to $1 / 10$, and then washed with 50 volumes of $0.14 \mathrm{M} \mathrm{NaCl}$ solution. The filtration dialysis aimed removing all material with molecular weight $<300,000$. After filtration the concentrated viral material was diluted to $10^{7}$ EID $50 / \mathrm{ml}$, aliquoted into cryotubes and stored at $-80^{\circ} \mathrm{C}$.

\section{Lyophilization of Sendai Virus in Allantoic Fluid Without Purification}

Virus-containing allantoic fluid was subjected to lyophilization. For this purpose $50 \mathrm{ml}$ of $5 \%$ stabilizing medium was mixed with $100 \mathrm{ml}$ of allantoic fluid. The stabilizing medium consisted of $10 \mathrm{~g}$ sucrose (Sigma-Aldrich, S0389) and 5 g lactalbumin hydrolysate (Sigma Aldrich, CAS Number: 91079-44-6) per $100 \mathrm{ml}$. The mixture was aliquoted into $1.5 \mathrm{ml}$ portions, placed into cryotubes, and subjected to lyophilization. This freeze drying procedure was carried out using a Christ alpha 1-4 LSC freeze-dryer (Martin Christ Freeze Dryers). After the lyophilization procedure and 
TABLE 1 | Outcomes of clinical testing of varying MCT treatment protocols.

\begin{tabular}{llll}
\hline $\boldsymbol{N}$ Name of chemical compound & $\begin{array}{l}\text { Number of } \\
\text { animals }\end{array}$ & $\begin{array}{l}\text { Type of disease } \\
\text { Side effects, grade, } \\
\text { percent of affected } \\
\text { animals (if reported) }\end{array}$ \\
\hline
\end{tabular}

$1 \quad$ Lomustine (CCNU), (cell cycle neutral) $\quad 19 \quad$ Grades 1-3 Neutropenia

Eight dogs had a measurable response. One dog had a durable complete response for 440 days. Seven dogs had a partial response for a median duration of 77 days. Six dogs had stable disease for a median duration of 78 days.

\begin{tabular}{ll}
\hline Lomustine & Non-resectable, grades 2 \\
& or 3
\end{tabular}

One dog showed partial response. Seven dogs had stable disease at the end of the study.

\begin{tabular}{lllll}
\hline 3 & Lomustine combined with prednisone & 12 & Incompletely excised, grade & Two fatal liver failures \\
& & 2
\end{tabular}

Seven dogs survived 2 years without disease progression. Two died from liver failure, indicating substantial liver toxicity of the two-drug combination.

4 Surgical cytoreduction, radiation
Eleven dogs were alive at least 1 year without evidence of disease progression. Seventeen dogs died or were euthanized because of disease progression. The
median disease free survival was 839 days. Median duration of overall survival was 845 days. Dogs with tumors $\leq 3 \mathrm{~cm}$ maximum diameter before surgery
survived longer than dogs with tumors $>3 \mathrm{~cm}$. The remission rate was $65 \%$ and survival rate was $71 \%$ at 1 year after treatment.

\begin{tabular}{llllll}
\hline 5 & $\begin{array}{l}\text { Surgical cytoreduction, radiation, prednisone } \\
\text { The median disease-free survival was 1,240 days. }\end{array}$ & Cutaneous MCT, stage 2 & Not reported \\
\hline 6 & Surgery, radiation, prednisone/vinblastine & 61 & High risk for metastasis & $\begin{array}{l}\text { Neutropenia, grades 3-4 } \\
\text { (6.5\%) }\end{array}$
\end{tabular}

Twenty-four dogs developed disease progression. The median progression-free interval was 1,305 days, and the median overall survival was not reached. Sixty-five percent of all animals were alive at 3 years, but all dogs with grade 2 disease were alive at 3 years. The median overall survival for dogs with grade 3 disease was 1,374 days.
7 Surgical cytoreduction, radiation, vinblastine, 21 lomustine, and prednisone
Grade 2, stage 2
Neutropenia, hepatotoxicity, grade $2-3$ toxicities (63\%)
(40)
Dogs that were treated with radiation, surgery, and chemotherapy had longer median overall survival than those that were treated only with surgery and chemotherapy $(2,056$ days vs. 1,103 , respectively).

\begin{tabular}{|c|c|c|c|}
\hline Vinblastine, lomustine, and prednisone & 17 & $\begin{array}{l}\text { Non-resectable, grades } 2 \\
\text { and } 3\end{array}$ & Hepatotoxicity (9\%) \\
\hline
\end{tabular}

Five showed a complete response and six a partial response. The median progression-free survival time among treated dogs was 489 days.

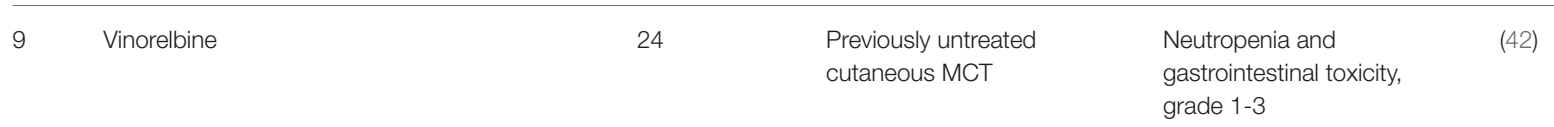

One dog achieved complete and two partial responses. The response was measured after only 1 week and only after single dose of the drug injection.

$10 \quad$ Prednosolone, chlorambucil $21 \quad \begin{aligned} & \text { Non-resectable, grades } 2 \\ & \text { and } 3\end{aligned} \quad$ Not reported

Three dogs achieved a complete response and five partial responses. The median progression-free interval for the eight responders was 533 days, and the median survival time for all dogs in the study was 140 days.

11 Paclitaxel (Paccal Vet) $29 \quad$\begin{tabular}{lll}
\hline & Non-resectable, grades 2 or & $\begin{array}{l}\text { Neutropenia, grades 3-4 (44) } \\
\text { and leucopenia, grades 1-2 }\end{array}$
\end{tabular}

Complete or partial responses were observed in more than half of the animals. The median time to progression in treated animals was 247 days.

\begin{tabular}{lll}
\hline Paclitaxel & 168 & $\begin{array}{l}\text { Advanced stage, } \\
\text { non-resectable, grades } 2 \text { or }\end{array}$ \\
3 & $\begin{array}{l}\text { Neutropenia or } \\
\text { gastrointestinal effects, } \\
\text { grades } 3 \text { and } 4(73 \%)\end{array}$ \\
Three percent of dogs showed complete and $\sim 60 \%$ partial response or stable disease at the end of the study. Paclitaxel treated dogs were 6.5 times more likely \\
than lomustine treated dogs to respond to chemotherapy.
\end{tabular}


TABLE 1 | Continued

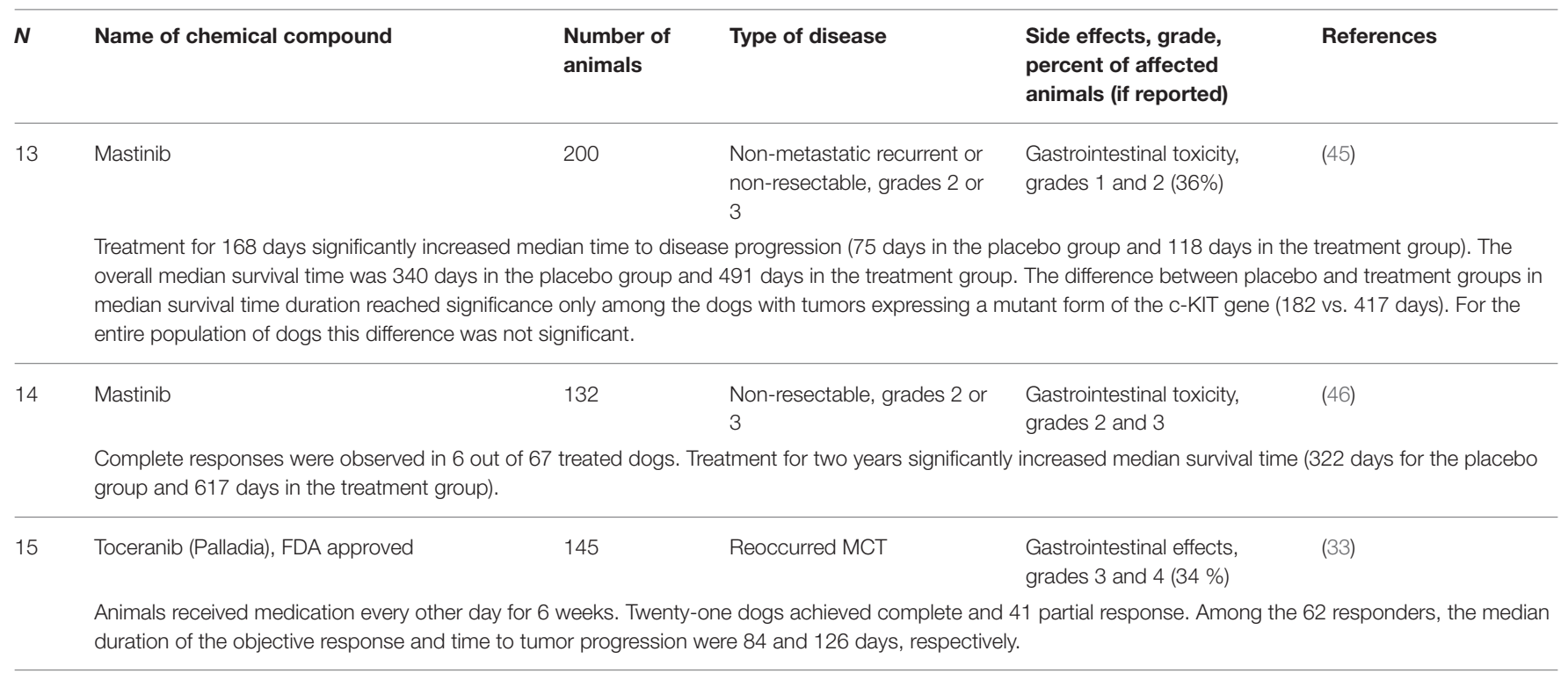

reconstitution in sterile water the virus titer was $10^{8.6}$ EID50/ml. The vials were stored at $-20^{\circ} \mathrm{C}$.

\section{Virus Treatment}

Virus treatments were administered at 2-week intervals for case 1 and 6 and 1-week intervals for the remaining cases. For each treatment up to ten $10-100 \mu \mathrm{l}$ aliquots from $1 \mathrm{ml}$ of virus preparation were injected into multiple sites intratumorally, intradermally around the tumor site and under the tumor bed. Injections containing virus purified by ultra-filtration with a titer of $10^{7}$ EID50/ml were administered in cases $1,2,3$, and 5 . The injections containing virus lyophilized directly from allantoic fluid with a titer of $10^{8.6} \mathrm{EID} 50 / \mathrm{ml}$ were administered in case 4 . RECIST evaluation criteria were used for assessing responses of tumors to the viral treatment.

\section{RESULTS}

Six canine patients underwent oncolytic Sendai virus treatment. Virotherapy was administered either as a monotherapy, or in a combination with surgery. The treatment was well tolerated; minor transitory side effects included fever, fatigue, and pain at the site of viral injection. The side effects were classified as grade 1 according to common terminology criteria for adverse events of the Veterinary Cooperative Oncology Group 2 (65). A side effects summary is presented in Table 2. Virotherapy treatment efficacy results are described below.

\section{Case 1}

Male dog of mixed breed, 7 years old, presented with ulcerated cutaneous mass ( $35 \mathrm{~mm}$ in diameter) located near his anal gland (Figure 1, Case 1). According to the dog's owner the tumor grew to the size of $35 \mathrm{~mm}$ during 3 weeks period. Fine-needle aspiration revealed that the tumor was poorly differentiated. The tumor stage was not assigned. Because of the tumor size
TABLE 2 | Summary of side effects that occurred during Sendai virus therapy.

\begin{tabular}{ll}
\hline Side effect & Occurrence \\
\hline Pyrexia (20 h after the injection) & Cases 2 and 3 \\
Asthenia & Cases 3 and 5 \\
Edema at the site of injection & Case 4 \\
Vomiting & 0 \\
Diarrhea & 0 \\
Pain or tenderness at site of injection & Case 3, 4, and 5 \\
Musculoskeletal pain & 0 \\
Decreased appetite & Case 3
\end{tabular}

All side effects were classified as grade 1 according to common terminology criteria for adverse events of the Veterinary Cooperative Oncology Group 2 (65).

and its proximity to anus, a complete surgical excision with clear margins was not possible. The treatment option was to try oncolytic virotherapy for tumor clearance. Sendai virus in a dose of $1 \mathrm{ml} 10^{7} \mathrm{EID} 50 / \mathrm{ml}$ was administered with 2-week intervals. The tumor was cleared after only two viral treatments; however two additional treatments were administered afterwards to ensure the effect. Three years after the treatment the dog does not have any signs of tumor recurrence. This dog was the first patient to receive the virus treatment at the Veterinary Clinic of the Herzen Oncology Research Institute. The absence of visible side effects in this dog encouraged more frequent (weekly) treatments for later canine patients.

\section{Case 2}

Male German shorthaired pointer, 9 years old, presented with subcutaneous MCT located in the elbow region (Figure 1, Case 2). Fine-needle aspiration revealed an intermediately differentiated tumor. The tumor was excised without clean margins. The surgery has curative intent, but only tumor 

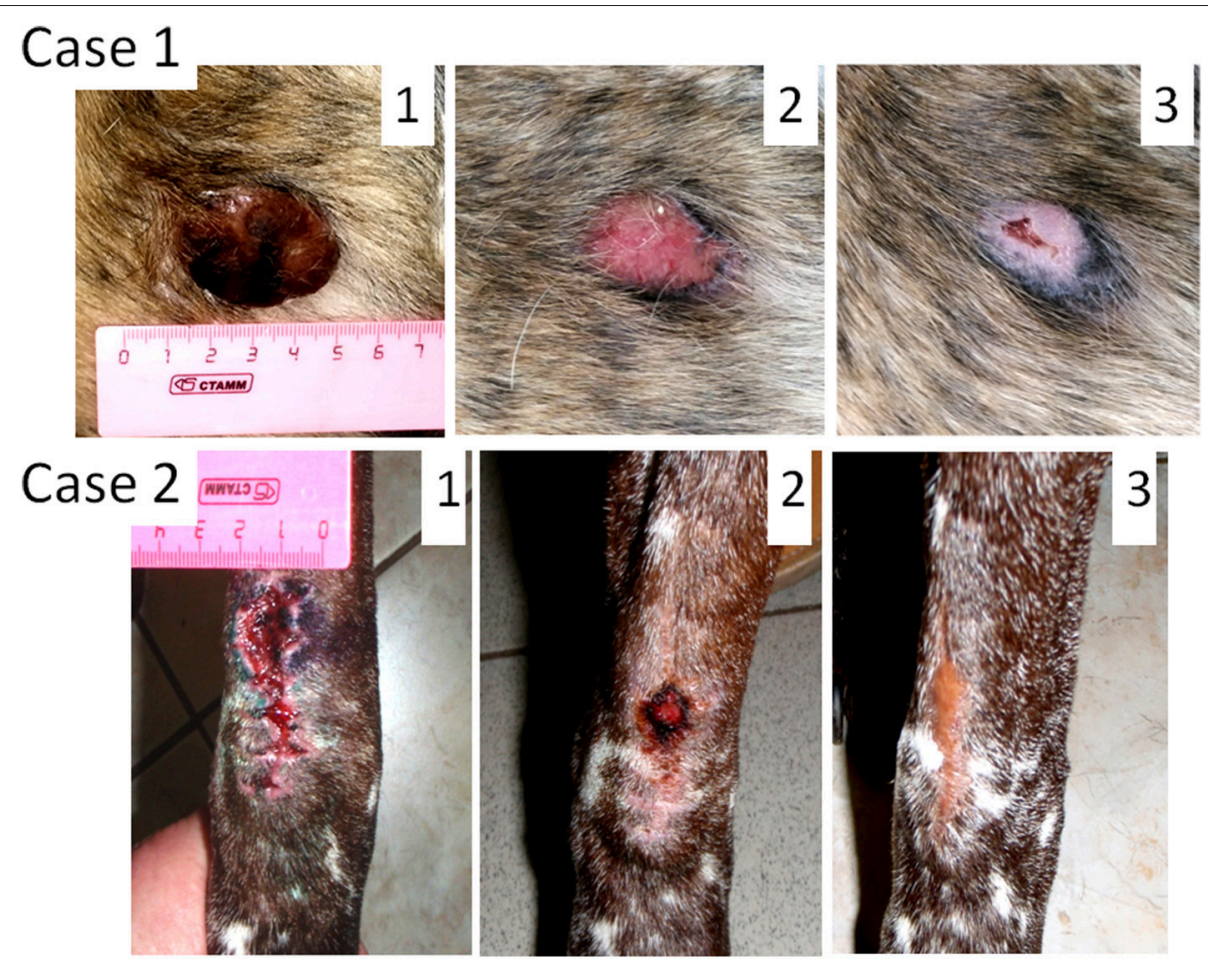

FIGURE 1 | Oncolytic Sendai virus MCT treatments results (Cases 1 and 2). Case 1. Male dog of mixed breed of 7 years old was presented with cutaneous, ulcerated, and poorly differentiated mastocytoma (35 mm diameter) located near his anus. The tumor stage was not assigned. (1) Primary tumor before any treatment; (2) MCT site, 2 weeks after the first virus treatment; (3) MCT site, 4 weeks after the first virus treatment. Case 2. Male German shorthaired pointer of 9 years old was presented with subcutaneous, regional (stage 2) intermediately differentiated mastocytoma. The primary tumor was excised without clean margins (is not shown). (1) MCT secondary growth 1 week after the surgical procedure; (2) MCT site, 2 weeks after the first virus treatment; (3) MCT site, 5 weeks after the first virus treatment.

debulking was achieved. Histological examination of the excised tumor mass revealed a mitotic index of $5(10 \times \mathrm{HPF})$ and confirmed that the tumor was intermediately differentiated. It was also noticed that the tumor penetrated underlying muscle tissue and therefore was staged as regional (stage 2). As expected, multiple lesions likely of the same tumor grade (tested by fineneedle aspiration) appeared at the surgical site 2 weeks after the surgery. They fused together to form a mass $40 \mathrm{~mm}$ in its longest diameter. Two subsequent virus treatments with 1-week interval have cleared the secondary growth. Three additional weekly treatments were applied to secure the effect. Each treatment included administration of $1 \mathrm{ml}$ of viral preparation $\left(10^{7} \mathrm{EID} 50 / \mathrm{ml}\right)$. Three years after the treatment the dog remains alive, without any signs of disease recurrence.

\section{Case 3}

Male dog of mixed breed, 10 years old, presented with subcutaneous MCT in the abdominal region (Figure 2, Case 3). Multiple palpable lymph nodes and cutaneous metastases were also detected. According to the owner the primary tumor grew fast, from 30 to $120 \mathrm{~mm}$ during a 3-week period. Through fineneedle aspiration the primary tumor and some tested metastases were graded as poorly differentiated. The tumor stage was assigned as "distant" or "stage 4." Since the radical surgical excision of all metastases was not possible the owner requested a debulking surgery, which has been performed. Histological examination of the excised tumor mass revealed a mitotic index of $9(10 \times \mathrm{HPF})$ and confirmed the tumor grade. As expected, multiple MCT lesions likely of the same tumor grade (tested by fine-needle aspiration) appeared at the surgical site. Nevertheless, three weekly Sendai virus treatments cleared completely all tumor nodules located at the site of surgical scar. Each treatment included administration of $1 \mathrm{ml}$ of the virus with a titer of $10^{7}$ EID50/ml delivered through multiple 0.01-0.1 ml injections directly and around the tumor as well as under the tumor bed. Additional $1 \mathrm{ml}$ of viral material with the same titer in 0.01$0.1 \mathrm{ml}$ doses was injected into visible metastatic nodules during each treatment. In total eight weekly applications of the virus were delivered in an attempt to clear metastases. However, even though some metastatic nodules shrank after the treatments, additional nodules continued to appear and grow. The dog was finally euthanized, 2 weeks after the last administration of the virus. Of note, in an attempt to improve quality of life the dog was treated with regular daily oral prednisone $(1 \mathrm{mg} / \mathrm{kg}) 28$ days before euthanasia.

\section{Case 4}

Female dog of mixed breed, 8.5 years old, presented with a cutaneous mass of $30 \mathrm{~mm}$ in diameter at the left thigh (Figure 2, Case 4). Fine-needle aspiration revealed intermediately differentiated MCT. The tumor stage was assigned as likely "localized" or "stage 1" but regional lymph-nodes were not 


\section{Case 3}
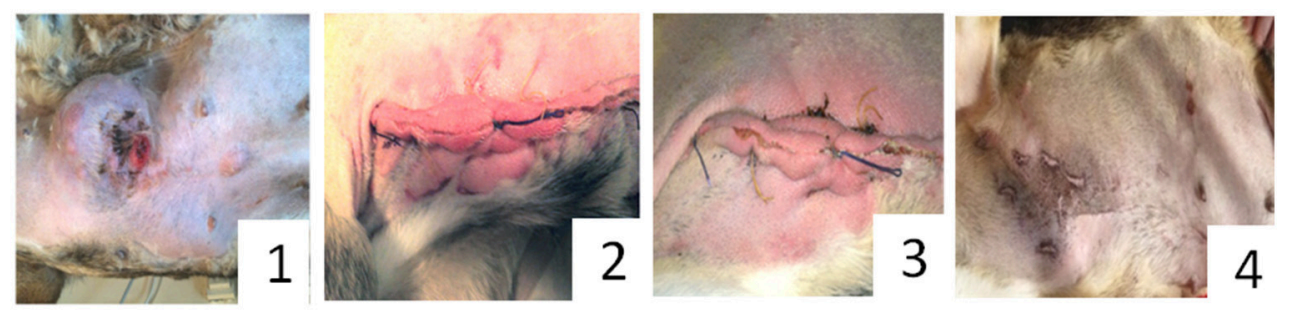

\section{Case 4}
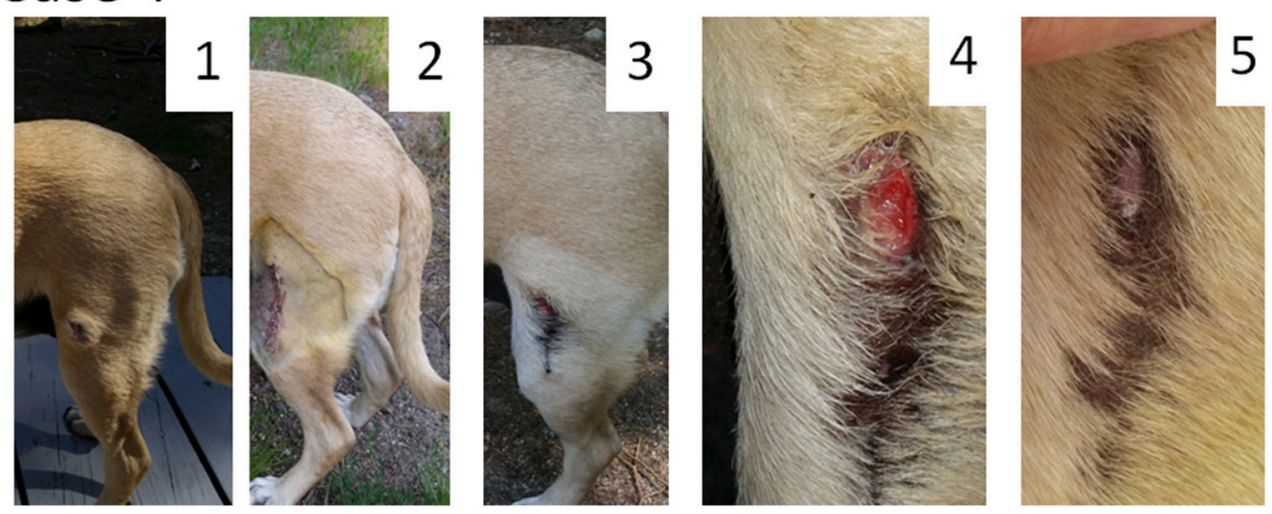

FIGURE 2 | Oncolytic Sendai virus MCT treatments results (Cases 3 and 4). Case 3. Male dog of mixed breed of 10 years old was presented with subcutaneous, distant (stage 4) poorly differentiated MCT located on abdomen with multiple palpable metastases. A debulking surgery has been performed. (1) Primary tumor before surgery (120 mm in diameter); (2) MCT secondary growth along the surgical scar, 4 days after the surgery; (3) MCT site, 1 week after the first viral treatment; (4) MCT site, 4 weeks after the first virus treatment. Case 4. Female dog of mixed breed of 8.5 years old was presented with cutaneous, local (stage 1) intermediately differentiated MCT. (1) Primary tumor (35 mm in diameter) before any treatment; (2) MCT site after complete surgical removal with at least $5 \mathrm{~mm}$ clean margins; (3) MCT relapse, 6 weeks after the surgery; (4) MCT site, 1 week after the first viral treatment; (5) MCT site, 2 weeks after the first virus treatment.

tested. MCT was subjected to virotherapy by administration of 10 weekly virus applications. The therapy did not clear the tumor mass, but the tumor stopped growing and didn't change its size during the treatment period. After the first round of virotherapy the tumor was surgically removed with curative intent and subjected to a histological examination that confirmed the initial diagnosis and revealed the presence of at least $5 \mathrm{~mm}$ clean surgical margins. The mitotic index of malignant cells was found to be equal to $0(10 \times \mathrm{HPF})$. Despite this low mitotic index, localized stage of MCT and comparatively large clean surgical margins, unexpected tumor relapse (tested by fine-needle aspiration) was noticed 6 weeks after the surgery. Nevertheless, resumed virus therapy completely cleared the recurrent tumor mass with only two weekly administrations of Sendai virus. Each treatment included $1 \mathrm{ml}$ of the virus $\left(10^{8.6} \mathrm{EID} 50 / \mathrm{ml}\right)$. One and a half years after the treatment the dog is live and does not have any signs of disease recurrence.

\section{Case 5}

Female dog of mixed breed, 13 years old, presented with a cutaneous interdigital mass of $15 \mathrm{~mm}$ in diameter (Figure 3, Case 5). Fine-needle aspiration revealed intermediately differentiated MCT. The tumor stage was not assigned because local lymph nodes were not probed. A radical curative surgery with clean margins was impossible because of the tumor location. A total resection of the foreleg was suggested, but rejected by the owner. MCT was subjected to Sendai virus therapy by administration of 12 weekly applications. The tumor was not cleared but remained the same in size during the virus treatment and 6 months thereafter. Secondary fine-needle aspiration was performed after the end of virus treatment. It confirmed the initial diagnosis as intermediately differentiated MCT, but revealed extensive necrotic areas in the analyzed sample. Nine months after initial diagnosis, a small trauma at the tumor site caused a painful degranulation event, which was treated with one prednisone injection $(2 \mathrm{mg} / \mathrm{kg})$. One week after the prednisone injection the tumor was surgically debulked ( $\sim 3 / 4$ of the mass was removed). Two weeks after the debulking surgery two consecutive weekly $1 \mathrm{ml}$ applications of the virus $\left(10^{7} \mathrm{EID} 50 / \mathrm{ml}\right)$ into the residual part of the tumor were performed. The remaining tumor mass ultimately regressed. The dog remained tumor free and died from unrelated causes 2 years later. Autopsy did not reveal MCT cells at the former tumor location site.

\section{Case 6}

Male golden retriever, 3 years old, presented with a cutaneous tumor mass $(20 \mathrm{~mm}$ in diameter) in the abdominal region (Figure 3, Case 6). The tumor was mildly inflamed with visible ulceration at its center. Fine-needle aspiration revealed highly differentiated MCT. Another highly differentiated MCT (30 mm 


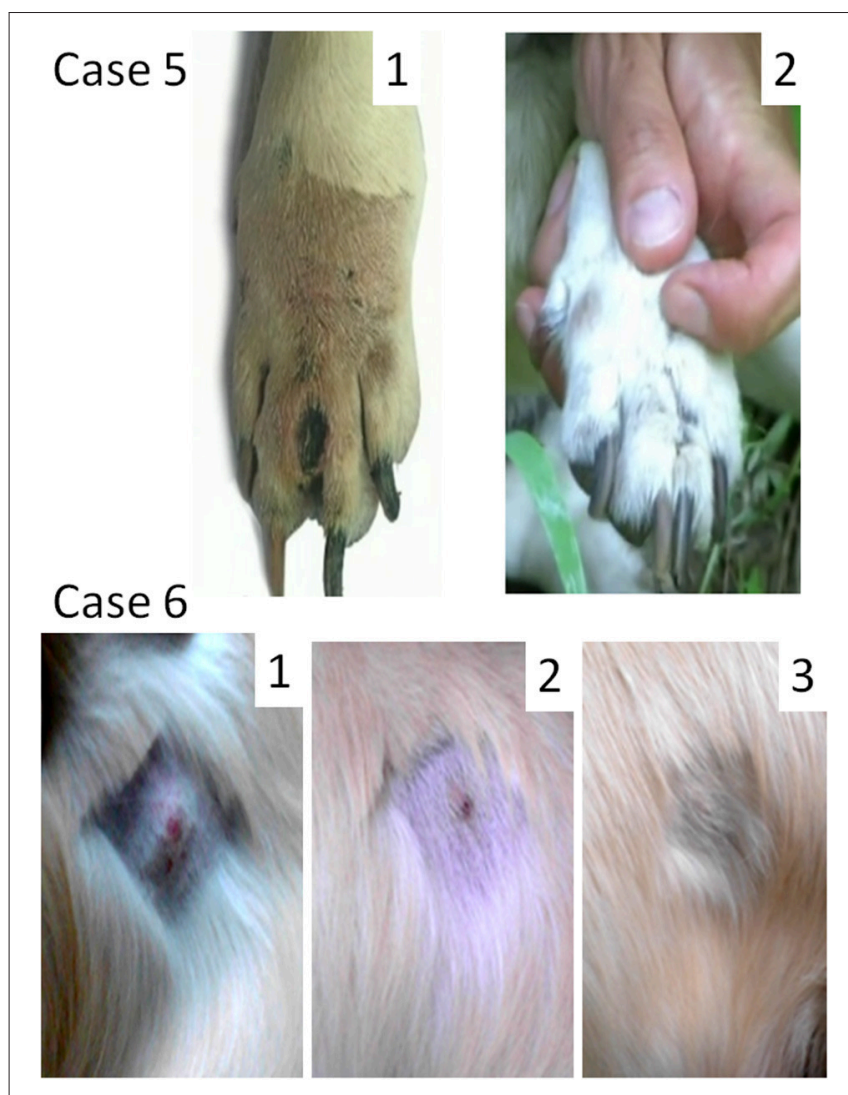

FIGURE 3 | Oncolytic Sendai virus MCT treatments results (Cases 5 and 6). Case 5. Female dog of mixed breed of 13 years old was presented with cutaneous intermediately differentiated inter-digital mass of $15 \mathrm{~mm}$. The disease stage was not assigned. (1) Inter-digital MCT, 1 week after prednisone injection and before a surgery; (2) MCT site after debulking surgery and 1 month after final virus treatment. Case 6. Male golden retriever of 3 years old was presented with cutaneous well differentiated MCT ( $20 \mathrm{~mm}$ in diameter) in the abdominal region. The disease stage was not assigned. (1) MCT (mildly inflamed with ulceration at its center) before the viral treatment; (2) MCT site 2 weeks after the first viral treatment; (3) MCT site 6 weeks after the first viral treatment.

in diameter), which was located near the stifle, was surgically removed 2 months prior. The stage of the abdominal tumor was not assigned as far as it was not clear if the new growing mass represented an independent primary MCT or a metastasis of the tumor that was already removed. Virotherapy was suggested and Sendai virus was administered with 2 -week intervals $\left[1 \mathrm{ml}\left(10^{7}\right.\right.$ EID50/ml)]. The tumor was completely cleared after three virus administrations (Figure 3, Case 6). Nevertheless, two additional applications were performed to secure the effect. One and half year after the treatment the dog remains alive without any signs of disease recurrence.

\section{DISCUSSION}

In this section we discuss the potential mechanism of Sendai virus oncolytic action, reasons for variable responses to the therapy, viral preparation, virus dosage, side effects, and a possible approach to their prevention.

\section{Potential Mechanism of Action}

All tested canine patients responded to the viral treatment completely or partially. What mechanism enabled the response? Sendai virus could specifically destroy malignant cells via a number of mechanisms outlined in two recent reviews $(66,67)$ and briefly summarized here.

\section{Direct Destruction of Cancer Cells}

One of the possible mechanisms of Sendai virus anticancer activity involves a selective direct destruction of cancer cells. This destruction is most likely promoted by higher affinity of Sendai virus to malignant rather than to normal cells and by the ability of Sendai virus to form syncytia.

Sialic acid polymers are cellular receptors for some paramyxoviruses including Sendai virus $(68,69)$. The virus has high affinity for its receptor. This high affinity toward sialic acid polymers promotes better binding of Sendai virus to malignant rather than to normal cells because density of sialic acid polymers on the cellular surface correlates with cellular malignancy (70-74).

Sendai virus, like other Paramyxoviruses, is able to spread through formation of large multinucleated structures. By inducing fusion of infected and uninfected cells the virus efficiently spreads without being exposed to neutralizing antibodies. The cell fusion structure, the syncytium, has a survival time of $<5$ days (75). A tumor cell, which is fused into a syncytium, cannot survive longer.

\section{Unmasking Cancer Antigens}

Malignant cells also could be destroyed through specific antitumor immunity triggered by Sendai virus. It could happen through unmasking cancer antigens, stimulation of natural killer (NK) and dendritic cells, and up-regulation of interferons and other cytokines. A high level of sialylation of cell membranes correlates with malignancy. Both invasive and metastatic abilities of tumor cells are associated with density of sialic acid polymers on their surfaces (70-74). Viral neuraminidase promotes desialylation of cell membranes $(68,75)$. Removal of sialic acids from the surface of tumor cells reduces their malignancy and increases immunogenicity, perhaps by unmasking cancer antigens and increasing tumor cell "visibility" to cytotoxic lymphocytes as well as to NK cells $(76,77)$. In addition, sialidasetreated and, consequently, desialylated tumor cells better activate NK cells for IFN-gamma production (76).

\section{Stimulation of Natural Killer Cells}

NK cells represent an important component of the innate immune system. NK cells can destroy virus-infected or malignant cells without prior antigen stimulation (78). A study of UVinactivated Sendai virus demonstrated that virus-mediated tumor regression is enhanced by NK cells (62).

\section{Stimulation of Dendritic Cells}

Dendritic cells (DCs) are specialized antigen-presenting cells that efficiently amplify both innate and acquired immune 
responses against various pathogens and malignant cells (79). A recombinant Sendai could trigger fast activation and maturation of DCs. Within an hour after ex vivo viral treatment DCs reach mature phenotype. Sendai virus-activated DCs dramatically improve the survival of animals affected by highly malignant melanoma (80). In model animals even UV-inactivated Sendai virus triggers strong infiltration of a tumor by DCs (60). Sendai virus activated DCs inoculated into animals prior to a tumor cell challenge prevented neuroblastoma growth and prostate adenocarcinoma metastasis into the lungs $(81,82)$. Similar results were obtained using DCs activated by different variants of recombinant Sendai virus strains with transplantable carcinomas including colorectal (83), squamous cell (84), hepatic and prostate cancers (59).

\section{Stimulation of Interferons}

The Sendai virus is an efficient trigger of interferon alpha secretion by human peripheral blood leukocytes (85). Even UVinactivated Sendai virus induces interferon-alpha and interferonbeta production in some tumor cell lines (63).

\section{Variation of Responses to Viral Treatment and Potential Mechanism of Sendai Virus Action}

This pilot study was not directed to treatment of most advanced stages of MCT. Among six dogs only one had confirmed distant metastases and the treatment with Sendai virus although produced positive response, was not curative for the dog. It is not known if the other dogs did or did not have metastases because they were not fully staged.

Despite the rather small sample size, we were able to observe a large spectrum of variable responses to oncolytic virus therapy. In cases 1 and 6 tumor masses were completely cleared without any surgical intervention, after no more than three consecutive virus applications. One of these tumors was poorly differentiated (case 1 ), while another was well differentiated (case 6). Two tumors of intermediate differentiation (cases 4 and 5) were stabilized only by multiple applications of the virus. However, the virus therapy completely eliminated the secondary tumor growth (case 4) or the tumor mass left after incomplete surgery (case 5). The therapy also completely cleared secondary growth of the intermediately differentiated MCT in case 2, but only partially stabilized the poorly differentiated tumor distant metastases in case 3. The animal in case 3 had most advanced disease (stage 4). Such diversity of responses could have many explanations including individual variability of tumors and their variable sensitivity to the virus, different amount of tumor load, differences in immune status of the dogs etc.

Most likely, malignant cells in the tumors that did not require surgical intervention were highly sensitive to viral infection, while cells in the remaining tumors were more resistant. The fast tumor clearance observed in cases 1 and 6 could be attributed to efficient viral infection and direct lysis of malignant cells. It is likely that the direct lysis was less efficient in cases 4 and 5 , because multiple viral treatments were unable to clear the tumors. Such clearance occurred only after surgery at a very early stage of tumor re-growth. We hypothesize that cells most resistant to the virus, could survive virotherapy and resume tumor growth proliferate, particularly in animals with a high tumor load, such as in case 3 . However, it is likely that a virus-stimulated immune system is able to clear minimal residual disease if the tumor load is comparatively low.

\section{Virus Preparation}

In this study we did not find much difference in the efficiency and manifestations of the two types of virus preparations. Even by using crude virus-containing allantoic fluid there was no significant adverse effects in the animals. Apparently, more clean preparations could be recommended for further studies to avoid potential adverse allergic reactions. The purification scheme for Sendai virus used in the study is relatively inexpensive and simple. However, we did not yet developed a lyophilization protocol for the purified virus, and storage conditions still requires deep freezing at $-80^{\circ} \mathrm{C}$.

\section{Treatment Dosages}

In this work we used two viral treatment dosages with titer $10^{7}$ or $10^{8.6}$ EID50 per $1 \mathrm{ml}$. The lower titer preparation was used in cases $1-3,5$, and 6 , and the preparation with the higher titer was used in case 4 . The lower-titer virus was able to clear the tumors, while the higher titer virus still did not cause any significant side effects. Therefore we can conclude that either of the doses appears to be acceptable for subsequent studies.

\section{Side Effects}

Side effects of the virus treatment were minor and transitory (Table 2). The most bothersome included slight tenderness and edema at the injection sites. Usually, these side effects resolved quickly without any intervention. Nevertheless, it was found that oral administration of diphenhydramine helped in eliminating these problems faster. Perhaps it would be helpful to prevent rather than treat potential pain or edema by using oral diphenhydramine before the virus treatments.

When possible, steroids were avoided. Steroid antiinflammatory medications are immuno-suppressive and may mitigate the beneficial virus-induced stimulation of antitumor immunity. However, in case 3, prednisone was used as palliative care, after failure of viral treatment.

Allergic reactions to egg products could represent a potential problem because Sendai virus preparations are derived from chicken embryos. We did not notice any allergic reactions in the treated dogs in our pilot study. However, as the possibility exists, a diagnostic skin test for egg allergies could identify vulnerable patients before the onset of virus therapy.

\section{CONCLUSIONS}

In summary, we conclude that

- Canine MCTs have different sensitivities to the oncolytic effects of Sendai virus. 
- Sendai virus generates a variety of antitumor responses among MCT affected animals, including complete tumor clearance without surgery, complete clearance of reoccurred tumors after surgery, and partial stabilization of the disease.

- Animals with localized disease and small tumor burden have a better chance for complete tumor clearance.

- Side effects of the described oncolytic virotherapy appear minor and transitory.

The Sendai virus mechanism of action does not appear to overlap with any known mechanisms of currently available conventional MCT treatments, thus effective combination protocols of virotherapy with these treatments could be developed. The ability of the virus to clear a remaining tumor after debulking surgery could lead to less intrusive surgical procedures and more frequent preservation of the affected limbs.

The oncolytic Sendai virus therapy of MCTs certainly has limitations; case 3 demonstrated that virus injections might be not helpful against metastases at very advanced stages of the disease. Cases 4 and 5 demonstrated that multiple Sendai virus treatments were only able to stabilize the disease before a surgical intervention. However, our pilot study suggests that Sendai virus

\section{REFERENCES}

1. Garrett LD. Canine mast cell tumors: diagnosis, treatment, and prognosis. Vet Med. (2014) 5:49-58. doi: 10.2147/VMRR.S41005

2. Sledge DG, Webster J, Kiupel M. Canine cutaneous mast cell tumors: a combined clinical and pathologic approach to diagnosis, prognosis, and treatment selection. Vet J. (2016) 215:43-54. doi: 10.1016/j.tvil.2016.06.003

3. Welle MM, Bley CR, Howard J, Rufenacht S. Canine mast cell tumours: a review of the pathogenesis, clinical features, pathology and treatment. Vet Dermatol. (2008) 19:321-39. doi: 10.1111/j.1365-3164.2008.00694.x

4. Dobson JM, Scase TJ. Advances in the diagnosis and management of cutaneous mast cell tumours in dogs. J Small Anim Pract. (2007) 48:424-31. doi: 10.1111/j.1748-5827.2007.00366.x

5. Leidinger EF, Freeman K, Kirtz G, Hooijberg EH, Sick K. Breed related odds ratio and anatomic distribution of canine mast cell tumours in Austria. Retrospective study of cases in the years 2000-2010. Tierarztl Prax Ausg K Kleintiere Heimtiere (2014) 42:367-73. doi: 10.15654/TPK140165

6. Warland J, Dobson J. Breed predispositions in canine mast cell tumour: a single centre experience in the United Kingdom. Vet J. (2013) 197:496-8. doi: 10.1016/j.tvjl.2013.02.017

7. Mochizuki H, Motsinger-Reif A, Bettini C, Moroff S, Breen M. Association of breed and histopathological grade in canine mast cell tumours. Vet Comp Oncol. (2016) 15:829-39. doi: 10.1111/vco.12225

8. Ammendola M, Sacco R, Sammarco G, Luposella M, Patruno R, Gadaleta CD, et al. Mast cell-targeted strategies in cancer therapy. Transfus Med Hemother. (2016) 43:109-13. doi: 10.1159/0004 44942

9. Vukman KV, Forsonits A, Oszvald A, Toth EA, Buzas EI. Mast cell secretome: soluble and vesicular components. Semin Cell Dev Biol. (2017) 67:65-7. doi: 10.1016/j.semcdb.2017.02.002

10. Bulfone-Paus S, Nilsson G, Draber P, Blank U, Levi-Schaffer F. Positive and negative signals in mast cell activation. Trends Immunol. (2017) 38:657-67. doi: 10.1016/j.it.2017.01.008

11. Elston LB, Sueiro FA, Cavalcanti JN, Metze K. The importance of the mitotic index as a prognostic factor for survival of canine cutaneous mast cell tumors: a validation study. Vet Pathol. (2009) 46:362-64. author reply: 364-5. doi: 10.1354/vp.46-2-362 can sometimes clear MCT even without surgery (cases 1 and 6); it indicates that the approach is promising, and deserving further studies.

\section{ETHICS STATEMENT}

This study was carried out in accordance with the recommendations of Guidelines for Institutional Animal Ethics Committees of the Russian Federation. The protocol was approved by the Animal Ethics Committees of Veterinary Clinic of Herzen Oncology Research Institute. Consents for experimental procedures were received from all animals owners.

\section{AUTHOR CONTRIBUTIONS}

GI and EM contributed equally to this work. GI was responsible for designing and supervising of clinical studies with dogs. EM performed all veterinary treatments for dogs. AS manufactured preparations of Sendai virus, performed virus titrations in chicken embryos. OM participated in designing experiments, compiling results, and writing the manuscript. PC initiated and coordinated the study and revised the manuscript.

12. Romansik EM, Reilly CM, Kass PH, Moore PF, London CA. Mitotic index is predictive for survival for canine cutaneous mast cell tumors. Vet Pathol. (2007) 44:335-41. doi: 10.1354/vp.44-3-335

13. Schultheiss PC, Gardiner DW, Rao S, Olea-Popelka F, Tuohy JL. Association of histologic tumor characteristics and size of surgical margins with clinical outcome after surgical removal of cutaneous mast cell tumors in dogs. J Am Vet Med Assoc. (2011) 238:1464-9. doi: 10.2460/javma.238.11.1464

14. Thompson JJ, Pearl DL, Yager JA, Best SJ, Coomber BL, Foster RA. Canine subcutaneous mast cell tumor: characterization and prognostic indices. Vet Pathol. (2011) 48:156-68. doi: 10.1177/0300985810387446

15. Thompson JJ, Yager JA, Best SJ, Pearl DL, Coomber BL, Torres RN, et al. Canine subcutaneous mast cell tumors: cellular proliferation and KIT expression as prognostic indices. Vet Pathol. (2011) 48:169-81. doi: 10.1177/0300985810390716

16. Patnaik AK, Ehler WJ, Macewen EG. Canine cutaneous mast cell tumor: morphologic grading and survival time in 83 dogs. Vet Pathol. (1984) 21:46974. doi: 10.1177/030098588402100503

17. Kiupel M, Webster JD, Bailey KL, Best S, Delay J, Detrisac CJ, Fitzgerald SD, et al. Proposal of a 2-tier histologic grading system for canine cutaneous mast cell tumors to more accurately predict biological behavior. Vet Pathol. (2011) 48:147-55. doi: 10.1177/0300985810386469

18. Preziosi R, Sarli G, Paltrinieri M. Prognostic value of intratumoral vessel density in cutaneous mast cell tumors of the dog. J Comp Pathol. (2004) 130:143-51. doi: 10.1016/j.jcpa.2003.10.003

19. Macfarlane MJ, Macfarlane LL, Scase T, Parkin T, Morris JS. Use of neutrophil to lymphocyte ratio for predicting histopathological grade of canine mast cell tumours. Vet Rec. (2016) 179:491. doi: 10.1136/vr.103650

20. Skor O, Fuchs-Baumgartinger A, Tichy A, Kleiter M, Schwendenwein I. Pretreatment leukocyte ratios and concentrations as predictors of outcome in dogs with cutaneous mast cell tumours. Vet Comp Oncol. (2016) 15:1333-45. doi: $10.1111 /$ vco. 12274

21. Jark PC, Mundin DB, De Carvalho M, Ferioli RB, Anai LA, Marchi FA, et al. Genomic copy number variation associated with clinical outcome in canine cutaneous mast cell tumors. Res Vet Sci. (2017) 111:26-30. doi: 10.1016/j.rvsc.2016.11.009

22. Arendt ML, Melin M, Tonomura N, Koltookian M, Courtay-Cahen $\mathrm{C}$, Flindall $\mathrm{N}$, et al. Genome-wide association study of golden retrievers identifies germ-line risk factors predisposing to mast cell 
tumours. PLoS Genet. (2015) 11:e1005647. doi: 10.1371/journal.pgen.10 05647

23. Fonseca-Alves CE, Bento DD, Torres-Neto R, Werner J, Kitchell B, LauferAmorim R. Ki67/KIT double immunohistochemical staining in cutaneous mast cell tumors from Boxer dogs. Res Vet Sci. (2015) 102:122-6. doi: 10.1016/j.rvsc.2015.08.007

24. Giantin M, Vascellari M, Morello EM, Capello K, Vercelli A, Granato A, Lopparelli RM, et al. c-KIT messenger RNA and protein expression and mutations in canine cutaneous mast cell tumors: correlations with post-surgical prognosis. J Vet Diagn Invest. (2012) 24:116-26. doi: 10.1177/1040638711425945

25. Kiupel M, Webster JD, Kaneene JB, Miller R, Yuzbasiyan-Gurkan V. The use of KIT and tryptase expression patterns as prognostic tools for canine cutaneous mast cell tumors. Vet Pathol. (2004) 41:371-7. doi: 10.1354/vp.41-4-371

26. Letard S, Yang Y, Hanssens K, Palmerini F, Leventhal PS, Guery S, et al. Gain-of-function mutations in the extracellular domain of KIT are common in canine mast cell tumors. Mol Cancer Res. (2008) 6:1137-45. doi: 10.1158/1541-7786.MCR-08-0067

27. Preziosi R, Morini M, Sarli G. Expression of the KIT protein (CD117) in primary cutaneous mast cell tumors of the dog. J Vet Diagn Invest. (2004) 16:554-61. doi: 10.1177/104063870401600610

28. Gil Da Costa RM. C-kit as a prognostic and therapeutic marker in canine cutaneous mast cell tumours: From laboratory to clinic. Vet J. (2015) 205:510. doi: 10.1016/j.tvjl.2015.05.002

29. Webster JD, Kiupel M, Yuzbasiyan-Gurkan V. Evaluation of the kinase domain of c-KIT in canine cutaneous mast cell tumors. BMC Cancer (2006) 6:85. doi: 10.1186/1471-2407-6-85

30. Webster JD, Yuzbasiyan-Gurkan V, Kaneene JB, Miller R, Resau JH, Kiupel $\mathrm{M}$. The role of c-KIT in tumorigenesis: evaluation in canine cutaneous mast cell tumors. Neoplasia (2006) 8:104-11. doi: 10.1593/neo.05622

31. Scarpa F, Sabattini S, Marconato L, Capitani O, Morini M, Bettini G. Use of histologic margin evaluation to predict recurrence of cutaneous malignant tumors in dogs and cats after surgical excision. J Am Vet Med Assoc. (2012) 240:1181-7. doi: 10.2460/javma.240.10.1181

32. Donnelly L, Mullin C, Balko J, Goldschmidt M, Krick E, Hume C, et al. Evaluation of histological grade and histologically tumour-free margins as predictors of local recurrence in completely excised canine mast cell tumours. Vet Comp Oncol. (2015) 13:70-6. doi: 10.1111/vco.12021

33. London CA, Malpas PB, Wood-Follis SL, Boucher JF, Rusk AW, Rosenberg MP, et al. Multi-center, placebo-controlled, double-blind, randomized study of oral toceranib phosphate (SU11654), a receptor tyrosine kinase inhibitor, for the treatment of dogs with recurrent (either local or distant) mast cell tumor following surgical excision. Clin Cancer Res. (2009) 15:3856-65. doi: 10.1158/1078-0432.CCR-08-1860

34. Rassnick KM, Moore AS, Williams LE, London CA, Kintzer PP, Engler SJ, et al. Treatment of canine mast cell tumors with CCNU (lomustine). J Vet Intern Med. (1999) 13:601-5. doi: 10.1111/j.1939-1676.1999.tb02217.x

35. Vail DM, Von Euler H, Rusk AW, Barber L, Clifford C, Elmslie R, et al. A randomized trial investigating the efficacy and safety of water soluble micellar paclitaxel (Paccal Vet) for treatment of nonresectable grade 2 or 3 mast cell tumors in dogs. J Vet Intern Med. (2012) 26:598-607. doi: 10.1111/j.1939-1676.2012.00897.x

36. Hosoya K, Kisseberth WC, Alvarez FJ, Lara-Garcia A, Beamer G, Stromberg PC, et al. Adjuvant CCNU (lomustine) and prednisone chemotherapy for dogs with incompletely excised grade 2 mast cell tumors. J Am Anim Hosp Assoc. (2009) 45:14-8. doi: 10.5326/04 50014

37. Hahn KA, King GK, Carreras JK. Efficacy of radiation therapy for incompletely resected grade-III mast cell tumors in dogs: 31 cases (19871998). J Am Vet Med Assoc. (2004) 224:79-82. doi: 10.2460/javma.2004.224.79

38. Chaffin K, Thrall DE. Results of radiation therapy in 19 dogs with cutaneous mast cell tumor and regional lymph node metastasis. Vet Radiol Ultrasound (2002) 43:392-5. doi: 10.1111/j.1740-8261.2002.tb01023.x

39. Thamm DH, Turek MM, Vail DM. Outcome and prognostic factors following adjuvant prednisone/vinblastine chemotherapy for high-risk canine mast cell tumour: 61 cases. J Vet Med Sci. (2006) 68:581-7. doi: 10.1292/jvms.68.581
40. Lejeune A, Skorupski K, Frazier S, Vanhaezebrouck I, Rebhun RB, Reilly $\mathrm{CM}$, et al. Aggressive local therapy combined with systemic chemotherapy provides long-term control in grade II stage 2 canine mast cell tumour: 21 cases (1999-2012). Vet Comp Oncol. (2015) 13:267-80. doi: 10.1111/vco.12042

41. Rassnick KM, Bailey DB, Russell DS, Flory AB, Kiselow MA, Intile JL, et al. A phase II study to evaluate the toxicity and efficacy of alternating CCNU and high-dose vinblastine and prednisone (CVP) for treatment of dogs with highgrade, metastatic or nonresectable mast cell tumours. Vet Comp Oncol. (2010) 8:138-52. doi: 10.1111/j.1476-5829.2010.00217.x

42. Grant IA, Rodriguez CO, Kent MS, Sfilgoi G, Gordon I, Davis G, et al. A phase II clinical trial of vinorelbine in dogs with cutaneous mast cell tumors. J Vet Intern Med. (2008) 22:388-93. doi: 10.1111/j.1939-1676.2008.0051.x

43. Taylor F, Gear R, Hoather T, Dobson J. Chlorambucil and prednisolone chemotherapy for dogs with inoperable mast cell tumours: 21 cases. J Small Anim Pract. (2009) 50:284-9. doi: 10.1111/j.1748-5827.2009.00732.x

44. Rivera P, Akerlund-Denneberg N, Bergvall K, Kessler M, Rowe A, Willmann $\mathrm{M}$, et al. Clinical efficacy and safety of a water-soluble micellar paclitaxel (Paccal Vet) in canine mastocytomas. J Small Anim Pract. (2013) 54:20-7. doi: 10.1111/j.1748-5827.2012.01304.x

45. Hahn KA, Ogilvie G, Rusk T, Devauchelle P, Leblanc A, Legendre A, et al. Masitinib is safe and effective for the treatment of canine mast cell tumors. $J$ Vet Intern Med. (2008) 22:1301-9. doi: 10.1111/j.1939-1676.2008.0190.x

46. Hahn KA, Legendre AM, Shaw NG, Phillips B, Ogilvie GK, Prescott DM, et al. Evaluation of 12- and 24-month survival rates after treatment with masitinib in dogs with nonresectable mast cell tumors. Am J Vet Res. (2010) 71:1354-61. doi: 10.2460/ajvr.71.11.1354

47. Von Euler H, Sadeghi A, Carlsson B, Rivera P, Loskog A, Segall T, et al. Efficient adenovector CD40 ligand immunotherapy of canine malignant melanoma. J Immunother. (2008) 31:377-84. doi: 10.1097/CJI.0b013e31816a812d

48. Westberg S, Sadeghi A, Svensson E, Segall T, Dimopoulou M, Korsgren O, et al. Treatment efficacy and immune stimulation by AdCD40L gene therapy of spontaneous canine malignant melanoma. J Immunother. (2013) 36:350-8. doi: 10.1097/CJI.0b013e31829d8a1b

49. Gentschev I, Patil SS, Petrov I, Cappello J, Adelfinger M, Szalay AA. Oncolytic virotherapy of canine and feline cancer. Viruses (2014) 6:2122-37. doi: 10.3390/v6052122

50. Macneill AL. On the potential of oncolytic virotherapy for the treatment of canine cancers. Oncolytic Virother. (2015) 4:95-107. doi: 10.2147/OV.S66358

51. Patil SS, Gentschev I, Nolte I, Ogilvie G, Szalay AA. Oncolytic virotherapy in veterinary medicine: current status and future prospects for canine patients. $J$ Transl Med. (2012) 10:3. doi: 10.1186/1479-5876-10-3

52. Institute of Laboratory Animal Resources (U.S.). Committee on Infectious Diseases of Mice and Rats. Infectious Diseases of Mice and Rats. Washington, DC: National Academy Press (1991).

53. Adderson E, Branum K, Sealy RE, Jones BG, Surman SL, Penkert R, et al. Safety and immunogenicity of an intranasal Sendai virus-based human parainfluenza virus type 1 vaccine in 3- to 6-year-old children. Clin Vaccine Immunol. (2015) 22:298-303. doi: 10.1128/CVI.00618-14

54. Slobod KS, Shenep JL, Lujan-Zilbermann J, Allison K, Brown B, Scroggs RA, et al. Safety and immunogenicity of intranasal murine parainfluenza virus type 1 (Sendai virus) in healthy human adults. Vaccine (2004) 22:3182-6. doi: 10.1016/j.vaccine.2004.01.053

55. Iwadate $\mathrm{Y}$, Inoue $\mathrm{M}$, Saegusa T, Tokusumi $\mathrm{Y}$, Kinoh $\mathrm{H}$, Hasegawa M, et al. Recombinant Sendai virus vector induces complete remission of established brain tumors through efficient interleukin-2 gene transfer in vaccinated rats. Clin Cancer Res. (2005) 11:3821-7. doi: 10.1158/1078-0432.CCR-04-1485

56. Kinoh $H$, Inoue $M$. New cancer therapy using genetically-engineered oncolytic Sendai virus vector. Front Biosci. (2008) 13:2327-34. doi: $10.2741 / 2847$

57. Kinoh H, Inoue M, Washizawa K, Yamamoto T, Fujikawa S, Tokusumi Y, et al. Generation of a recombinant Sendai virus that is selectively activated and lyses human tumor cells expressing matrix metalloproteinases. Gene Ther. (2004) 11:1137-45. doi: 10.1038/sj.gt.3302272

58. Tatsuta K, Tanaka S, Tajiri T, Shibata S, Komaru A, Ueda Y, et al. Complete elimination of established neuroblastoma by synergistic action of gammairradiation and DCs treated with $\mathrm{rSeV}$ expressing interferon-beta gene. Gene Ther. (2009) 16:240-51. doi: 10.1038/gt.2008.161 
59. Yonemitsu Y, Ueda Y, Kinoh H, Hasegawa M. Immunostimulatory virotherapy using recombinant Sendai virus as a new cancer therapeutic regimen. Front Biosci. (2008) 13:1892-8. doi: 10.2741/2809

60. Kurooka M, Kaneda Y. Inactivated Sendai virus particles eradicate tumors by inducing immune responses through blocking regulatory T cells. Cancer Res. (2007) 67:227-36. doi: 10.1158/0008-5472.CAN-06-1615

61. Kawano H, Komaba S, Yamasaki T, Maeda M, Kimura Y, Maeda A, et al. New potential therapy for orthotopic bladder carcinoma by combining HVJ envelope with doxorubicin. Cancer Chemother Pharmacol. (2008) 61:973-8. doi: 10.1007/s00280-007-0553-1

62. Fujihara A, Kurooka M, Miki T, Kaneda Y. Intratumoral injection of inactivated Sendai virus particles elicits strong antitumor activity by enhancing local CXCL10 expression and systemic NK cell activation. Cancer Immunol Immunother. (2008) 57:73-84. doi: 10.1007/s00262-007-0351-y

63. Kawaguchi Y, Miyamoto Y, Inoue T, Kaneda Y. Efficient eradication of hormone-resistant human prostate cancers by inactivated Sendai virus particle. Int J Cancer (2009) 124:2478-87. doi: 10.1002/ijc.24234

64. Giles RE, Ruddle FH. Production of Sendai virus for cell fusion. In Vitro (1973) 9:103-7. doi: 10.1007/BF02616007

65. Veterinary cooperative oncology group - common terminology criteria for adverse events (VCOG-CTCAE) following chemotherapy or biological antineoplastic therapy in dogs and cats v1.1. Vet Comp Oncol. (2016) 14:41746. doi: $10.1111 /$ vco. 283

66. Matveeva OV, Guo ZS, Shabalina SA, Chumakov, PM. Oncolysis by paramyxoviruses: multiple mechanisms contribute to therapeutic efficiency. Mol Ther Oncolytics (2015) 2:15011. doi: 10.1038/mto.2015.11

67. Matveeva OV, Kochneva GV, Netesov SV, Onikienko SB, Chumakov PM. Mechanisms of oncolysis by paramyxovirus Sendai. Acta Nat. (2015) 7:6-16.

68. Bossart KN, Fusco DL, Broder CC. Paramyxovirus entry. Adv Exp Med Biol. (2013) 790:95-127. doi: 10.1007/978-1-4614-7651-1_6

69. Villar E, Barroso IM. Role of sialic acid-containing molecules in paramyxovirus entry into the host cell: a minireview. Glycoconj J. (2006) 23:5-17. doi: 10.1007/s10719-006-5433-0

70. Bresalier RS, Rockwell RW, Dahiya R, Duh QY, Kim YS. Cell surface sialoprotein alterations in metastatic murine colon cancer cell lines selected in an animal model for colon cancer metastasis. Cancer Res. (1990) 50:1299-307.

71. Bull C, Stoel MA,Den Brok MH, Adema GJ. Sialic acids sweeten a tumor's life. Cancer Res. (2014) 74:3199-204. doi: 10.1158/0008-5472.CAN-14-0728

72. Bull C, Den Brok MH, Adema GJ. Sweet escape: sialic acids in tumor immune evasion. Biochim Biophys Acta (2014) 1846:238-46. doi: 10.1016/j.bbcan.2014.07.005

73. Pearlstein E, Salk PL, Yogeeswaran G, Karpatkin S. Correlation between spontaneous metastatic potential, platelet-aggregating activity of cell surface extracts, and cell surface sialylation in 10 metastatic-variant derivatives of a rat renal sarcoma cell line. Proc Natl Acad Sci USA. (1980) 77:4336-9. doi: 10.1073/pnas.77.7.4336

74. Yogeeswaran G, Salk PL. Metastatic potential is positively correlated with cell surface sialylation of cultured murine tumor cell lines. Science (1981) 212:1514-6. doi: 10.1126/science.7233237

75. Lamb RA, Parks GD. Paramyxoviridae: the viruses and their replication. In: Knipe DM, Howley PM, editors. Fields Virology, 5th ed. Philadelphia, PA: Lippincott Williams \& Wilkins (2007). p. 1449-96.
76. Cohen M, Elkabets M, Perlmutter M, Porgador A, Voronov E, Apte RN, et al. Sialylation of 3-methylcholanthrene-induced fibrosarcoma determines antitumor immune responses during immunoediting. J Immunol. (2010). 185:5869-78. doi: 10.4049/jimmunol.1001635

77. Vierbuchen M, Schroder S, Larena A, Uhlenbruck G, Fischer R. Native and sialic acid masked Lewis(a) antigen reactivity in medullary thyroid carcinoma. Distinct tumour-associated and prognostic relevant antigens. Virchows Arch. (1994) 424:205-11. doi: 10.1007/BF00193501

78. Mandal A, Viswanathan C. Natural killer cells: In health and disease. Hematol Oncol Stem Cell Ther. (2015) 8:47-55. doi: 10.1016/j.hemonc.2014.11.006

79. Sato K, Fujita S. Dendritic cells: nature and classification. Allergol Int. (2007) 56:183-91. doi: 10.2332/allergolint.R-06-139

80. Shibata S, Okano S, Yonemitsu Y, Onimaru M, Sata S, Nagata-Takeshita $\mathrm{H}$, et al. Induction of efficient antitumor immunity using dendritic cells activated by recombinant Sendai virus and its modulation by exogenous IFN-beta gene. J Immunol. (2006) 177:3564-76. doi: 10.4049/jimmunol.177.6. 3564

81. Kato T, Ueda Y, Kinoh H, Yoneyama Y, Matsunaga A, Komaru A, et al. RIGI helicase-independent pathway in sendai virus-activated dendritic cells is critical for preventing lung metastasis of AT 6.3 prostate cancer. Neoplasia (2010) 12:906-14. doi: 10.1593/neo.10732

82. Komaru A, Ueda Y, Furuya A, Tanaka S, Yoshida K, Kato T, et al. Sustained and NK/CD4+ $\mathrm{T}$ cell-dependent efficient prevention of lung metastasis induced by dendritic cells harboring recombinant Sendai virus. J Immunol. (2009) 183:4211-9. doi: 10.4049/jimmunol.08 03845

83. Sugiyama M, Kakeji Y, Tsujitani S, Harada Y, Onimaru M, Yoshida K, et al. Antagonism of VEGF by genetically engineered dendritic cells is essential to induce antitumor immunity against malignant ascites. Mol Cancer Ther. (2011) 10:540-9. doi: 10.1158/1535-7163.MCT-10-0479

84. Yoneyama Y, Ueda Y, Akutsu Y, Matsunaga A, Shimada H, Kato T, et al. Development of immunostimulatory virotherapy using non-transmissible Sendai virus-activated dendritic cells. Biochem Biophys Res Commun. (2007) 355:129-35. doi: 10.1016/j.bbrc.2007.01.132

85. Nyman TA, Tolo H, Parkkinen J, Kalkkinen N. Identification of nine interferon-alpha subtypes produced by Sendai virus-induced human peripheral blood leucocytes. Biochem J. (1998) 329:295-302. doi: 10.1042/bj32 90295

Conflict of Interest Statement: The study was supported by Ministry of Science and Education of Russia, project code RFMEFI60714X0014 and by SATOR Therapeutics BioEnterprise. The funders had no a role in study design, data collection and analysis, decision to publish, or preparation of the manuscript. All the authors declare no other conflict of interest.

Copyright (c) 2018 Ilyinskaya, Mukhina, Soboleva, Matveeva and Chumakov. This is an open-access article distributed under the terms of the Creative Commons Attribution License (CC BY). The use, distribution or reproduction in other forums is permitted, provided the original author(s) and the copyright owner are credited and that the original publication in this journal is cited, in accordance with accepted academic practice. No use, distribution or reproduction is permitted which does not comply with these terms. 